\title{
Organic matter in rock-water systems of petroliferous basins: interrelationships (a case study: South Caspian Basin)
}

\author{
Akper A. Feyzullayev ${ }^{1}$ and Ian Lerche $^{2, *}$ \\ ${ }^{1}$ Institute of Geology and Geophysics of Azerbaijan National Academy of Sciences, H.Cavid av. 119, Baku AZ1143, Azerbaijan \\ ${ }^{2}$ Institut für Geowissenschaften, Naturwissenschaftliche Fakultät III, Martin-Luther-Universität, 06132 Halle (Saale), Germany
}

Received: 22 November 2018 / Accepted: 6 August 2019

\begin{abstract}
Generalizations and analyses are given of the data accumulated to date on the content of Organic Matter (OM) in formation waters of various stratigraphic complexes, as well as of mud volcanoes, and the correlation with OM in South Caspian Basin (SCB) sedimentary rocks. Results are based on about 300 analyses of formation waters and waters of mud volcanoes, as well as on more than 400 analyses of the content of OM in rocks (outcrops and wells from both onshore and offshore petroleum fields of the SCB). The stratigraphic interval covers the period from the Lower Pliocene to the Jurassic, and the depth interval from $73 \mathrm{~m}$ to $6043 \mathrm{~m}$. In these intervals, the values of Dissolved Organic Matter (DOM) in reservoir waters vary from $4.1 \mathrm{mg} / \mathrm{L}$ to $271.2 \mathrm{mg} / \mathrm{L}$, averaging (219 analyses) $48.9 \mathrm{mg} / \mathrm{L}$. A good correlation has been established between the values of DOM and OM in rocks. Paleogene and Jurassic rocks have the highest correlations. DOM varies with depth with an increase in value from a depth of about $3.3 \mathrm{~km}$, likely due to catagenetic transformation of OM into hydrocarbons in the rock-water system. The highest values of DOM are for waters with mineralization less than $50 \mathrm{~g} / \mathrm{L}$. Mud volcano waters are characterized by low levels of DOM and low mineralization, likely due to the condensate nature. The results of the studies show that underground water, as one of the components of a single rock-water system of the Earth's sedimentary cover, together with the rocks, participates in the processes of hydrocarbon generation and migration.
\end{abstract}

\section{Introduction}

The widespread occurrence of sedimentary rocks together with modern sediments lining the bottom of the world's oceans and terrigenous basins form a cover of the Earth. The thickness of the cover varies widely from 0 to 20-30 km. The total volume of sedimentary cover rocks is estimated at $1.1 \times 10^{9}$ million $\mathrm{km}^{3}$, which is about $11 \%$ of the Earth's crust [1]. Current concepts suggest that all voids in sedimentary rocks (except for hydrocarbon deposits) are filled with water below the groundwater level. According to available estimates [2], about $3.0 \times 10^{23} \mathrm{~g}$ water is contained in the sedimentary cover. In the South Caspian Basin (SCB), the volume of these waters is estimated at about $5.3 \times 10^{20} \mathrm{~g}$. Groundwater is represented both in free and bound (adsorbed) forms. Vernadskiy [3] pointed out the important role of water in geological processes and noted that the water composition is a function of the long evolution of the water-rock-gas-OM system.

The fundamental property of this system is its equilibrium-nonequilibrium state [3-6]. Water is in continuous interaction with the mineral skeleton of the rocks, maximal

\footnotetext{
* Corresponding author: lercheian@yahoo.com
}

in finely dispersed (clay) rocks that form about $70 \%$ of the total sedimentary rock volume. Water-rock interaction processes (ion exchange, dissolution and precipitation) are responsible for the chemical aspects of mineral diagenesis [7-10].

Understanding these processes is extremely important in the petroleum industry because they lead to major increases or decreases in the porosity and permeability of reservoir rocks.

Water at all stages of interaction with rocks continuously concentrates some elements and dissipates others, as manifested by regular changes in the composition of the aqueous solution.

Removal of mobile mineral and Organic Matter (OM) from the rocks is accompanied by a gradual increase in their concentration in the pore waters.

Water-soluble OM can be inherited not only from connate waters, but also includes OM that has passed into the groundwater from rocks during lithogenesis. Altovskiy et al. [11] showed that transitions of OM in the water-rock system are determined by the ratio of their concentrations and the sorption capacity of the rocks. At the same time, the enrichment of rocks with dispersed OM has a significant influence on the value of the DOM content in underground 
waters $[12,13]$. The total amount of $\mathrm{OM}$ in groundwater is dependent on the amount of $\mathrm{OM}$ in many natural processes and second only to its content in sedimentary rocks [2].

Theoretical and experimental studies $[11,14,15]$ made it possible to establish an identical distribution of $\mathrm{OM}$ in the formation water and in the water-bearing rock system. These studies served as the original basis for the concept of participation of OM and DOM in oil and gas generation $[11,16]$. The content of DOM, like OM of rocks, is regulated mainly by such factors as the evolution of the sedimentary basin, the intensity of the $\mathrm{OM}$ introduced from the surrounding land by water flow, the sedimentation environment, lithogenetic processes, etc. Enrichment of rocks with OM has a significant influence on the value of the DOM content in underground waters [12] (Tab. 1).

This article is not particularly concerned directly with commercial interests but rather, based on the example of the SCB, shows that DOM plays a secondary role in the formation of oil and gas fields and participates in the process of hydrocarbon generation together with the source rocks. One major point should, perhaps, be emphasized to minimize potential confusion. This article demonstrates that DOM in the SCB can be a source of oil and/or gas. While the amount of hydrocarbons produced by DOM may not play a dominant role in the formation of oil and gas fields, nevertheless one needs to be somewhat circumspect when comparing hydrocarbons produced by $\mathrm{OM}$ in rocks and those produced by DOM. The point is that flowing water carries DOM with it unlike OM in rocks. Thus the relative locations of hydrocarbons produced by DOM compared to those produced by $\mathrm{OM}$ in rocks depend on the total fluid history of the basin, where and when the OM was converted into hydrocarbons and the subsequent history of those hydrocarbons flowing either on their own or in water solution. By way of contrast one has a similar problem for DOM in water solution and when any of the DOM was converted to hydrocarbons and their subsequent history. A direct comparison of DOM and OM does not include such a development and can lead one to dismiss DOM as a potential contributor to hydrocarbon involvement because it ignores the later locations of produced hydrocarbons from both DOM and OM. There is also the concern that present-day measurements of DOM and OM do not represent produced hydrocarbons but rather represent the future potential of DOM and OM for producing hydrocarbons. The amount of hydrocarbons that has been produced through to the present-day is not given by such estimates. In short one needs to have a complete history including production, migration and accumulation and a way of estimating whether hydrocarbons so produced in the past are still retained in the accumulation sites or whether they have leaked away with time.

As a consequence only the fundamental aspect of this problem is considered here. The results show that not only the rocks but also the water contained in them participate in the hydrocarbon generation process. Our task is not a quantitative comparison of the two likely sources of hydrocarbons (including a complete basin analysis of the timing of production, later motion and locations after production [something that is well beyond the scope of the present
Table 1. The dependence of the content of $\mathrm{C}_{\text {org }}$ in water from enrichment rocks with organic matter [12].

\begin{tabular}{lcc}
\hline $\begin{array}{l}\text { Age of } \\
\text { rocks }\end{array}$ & $\begin{array}{c}\mathrm{C}_{\text {org }} \text { of rocks } \\
(\%)\end{array}$ & $\begin{array}{c}\mathrm{C}_{\text {org }} \text { of subsurface waters } \\
(\mathrm{mg} / \mathrm{L})\end{array}$ \\
\hline Neogene & 0.9 & 14.4 \\
Paleogene & 0.9 & 8.3 \\
Cretaceous & 0.5 & 4.2 \\
Palaeozoic & 0.3 & 2.6 \\
\hline
\end{tabular}

article]) but rather use of available data in the SCB to discuss the present-day patterns of DOM and OM with depth and basin location. As shown throughout there are both interesting differences and similarities between DOM and OM which can be used to suggest the histories of both in a qualitative fashion in the absence of a detailed basin analysis.

For the eastern part of the Azov-Kuban and western parts of the Middle Caspian oil and gas basins Bars et al. [17] have established the apparent positive dependence of the DOM concentration in groundwater on the OM concentration in the water-bearing rocks, based on analysis of more than 1500 different parameters of the OM composition in waters and about 3000 determinations of the $\mathrm{OM}$ composition in the rocks (Fig. 1).

The SCB is one of the oldest and well studied oil and gas basins. However, specific studies on the analysis of regional regularities of the $\mathrm{OM}$ distribution in groundwater, their connection with OM of rocks, the role of the DOM in oil and gas generation have not yet been given. Generalizations and analyses are given of the data accumulated to date on the content of $\mathrm{OM}$ in formation waters of various stratigraphic complexes, as well as of mud volcanoes, and the correlation with $\mathrm{OM}$ in SCB sedimentary rocks.

\section{Database and methods}

Results are based on about 300 analyses of formation waters and waters of mud volcanoes, as well as more than 400 analyses on the content of OM in rocks of the SCB. The stratigraphic interval covers the period from the Lower Pliocene to the Jurassic, and depth interval from $73 \mathrm{~m}$ to $6043 \mathrm{~m}$. The Total Organic Carbon (TOC) content in rocks was determined by the direct combustion method: crushed shale samples were acid treated in a filtering crucible to remove carbonate, combusted at about $1000{ }^{\circ} \mathrm{C}$, and analyzed as carbon dioxide. This TOC is taken to represent OM in rocks although there is always the uncertainty of knowing aliphatic and aromatic relative contributions. Pyrolysis data of rocks, made on a Rock-Eval device, was also used. In total about 400 values of TOC and rock pyrolysis were used obtained from outcrops and wells from both onshore and offshore petroleum fields.

Determination of Dissolved Organic Matter (DOM) consists in preliminary processing of a water sample by hydrochloric acid, removal of carbon dioxide formed from 


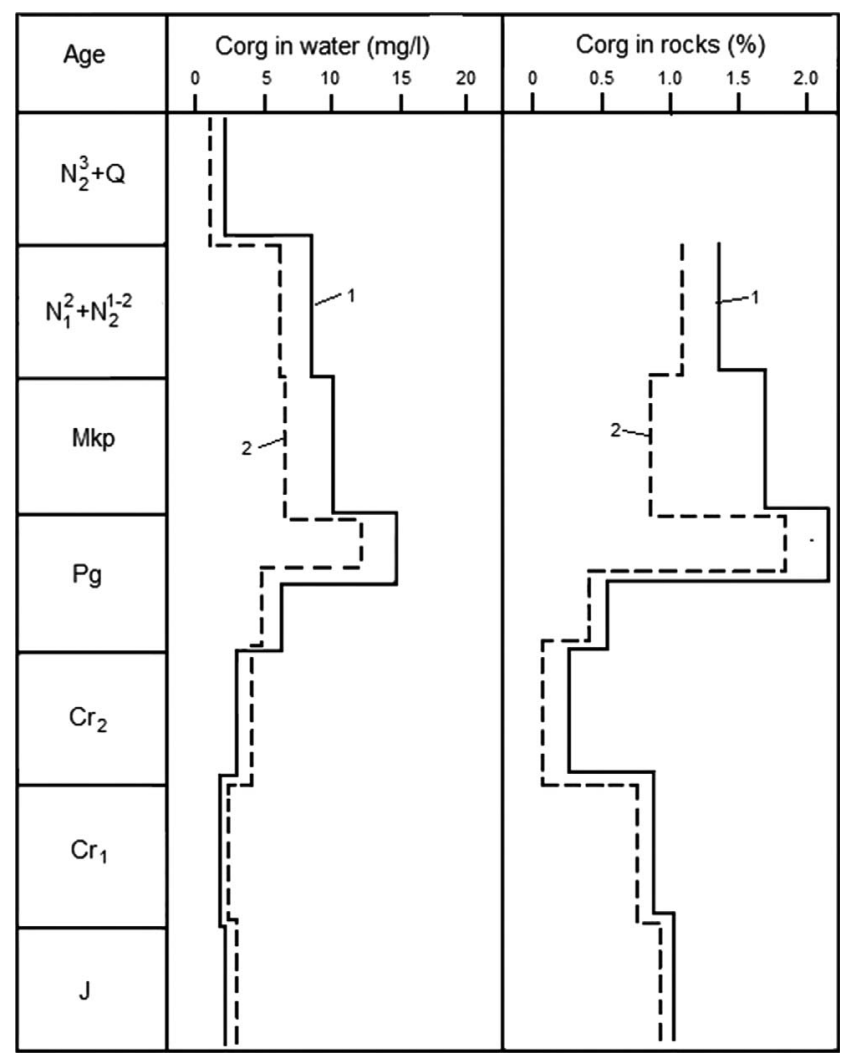

Fig. 1. The content of $\mathrm{C}_{\text {org }}$ in the waters and rocks of Ciscaucasia: 1, Azov-Kuban Basin; 2, Middle-Caspian Basin as inferred from organic carbon measurements [17].

carbonates and hydrocarbonates, oxidation of the organic carbon compounds in the sample at temperature from $550{ }^{\circ} \mathrm{C}$ up to $1000{ }^{\circ} \mathrm{C}$ in the presence of oxygen or oxygen-containing gas, catalysis to carbon dioxide and subsequent determination of the total carbon with use of an infrared radiation detector.

\section{Results and discussion}

The SCB occupies a vast depression area of the Earth's crust, including the southern part of the Kura intermountain trough, the West Turkmen depression and the deepsea basin of the Southern Caspian located between them. Hydrogeologically the SCB is a classical connate basin [18]. The content of OM in the rocks of the sedimentary complex of the SCB has been previously studied primarily on natural outcrops of different stratigraphic ages [19-21]. According to these studies, the rocks of the MioceneOligocene deposits, which are referred to as oil source deposits [21-24] have the highest values of TOC. The TOC values, averaged over individual stratigraphic complexes, show an uneven distribution [25]. The maximum OM contents were distinctive for Maikop (Oligocene-Lower Miocene) sediments. Jurassic rocks are also distinguished by elevated TOC values (Fig. 2).

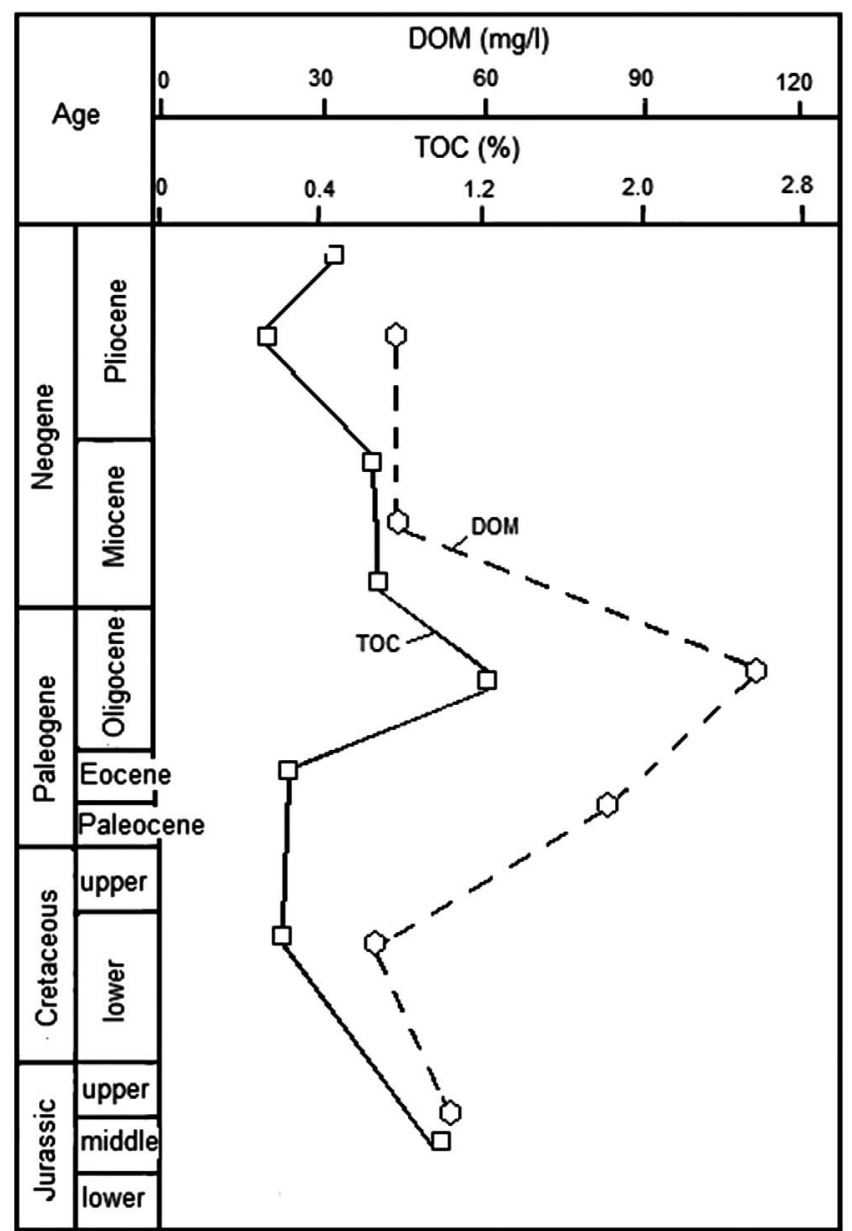

Fig. 2. Stratigraphic control of variations in average values of TOC in rocks and DOM in the South Caspian Basin [25].

DOM varied from $4.1 \mathrm{mg} / \mathrm{L}$ to $271.2 \mathrm{mg} / \mathrm{L}$. The average value for 219 analyses was $48.9 \mathrm{mg} / \mathrm{L}$, which agrees well with estimates for other basins for which dissolved $\mathrm{OM}$ in underground aquifers of oil and gas basins does not exceed $50 \mathrm{mg} / \mathrm{L}[26,27]$. The change in average values of DOM is in good agreement with the TOC change in rocks. A deviation towards higher values of $\mathrm{OM}$ in the waters in comparison with the rocks is noted only for the EocenePliocene interval of the section. The OM variation in formation waters of the various stratigraphic complexes of the SCB is more clearly demonstrated by the distribution histograms of Figure 3. The histograms showed that in water as well as in rocks the highest values are characteristic for oil-source Paleogene-Miocene and Jurassic deposits. The lowest concentrations of $\mathrm{OM}$ are for mud volcano waters.

The correlation between $\mathrm{OM}$ in waters and their surrounding rocks permits the conclusion that a dynamic equilibrium is established between the rock and water that are constituent parts of a single rock-fluid system and are in continuous interaction over geological time. Accordingly, Cai et al. [28] supposed that very negative $\delta \mathrm{D}$ values and positive $\delta^{18} \mathrm{O}$ values in the oilfield waters of the 


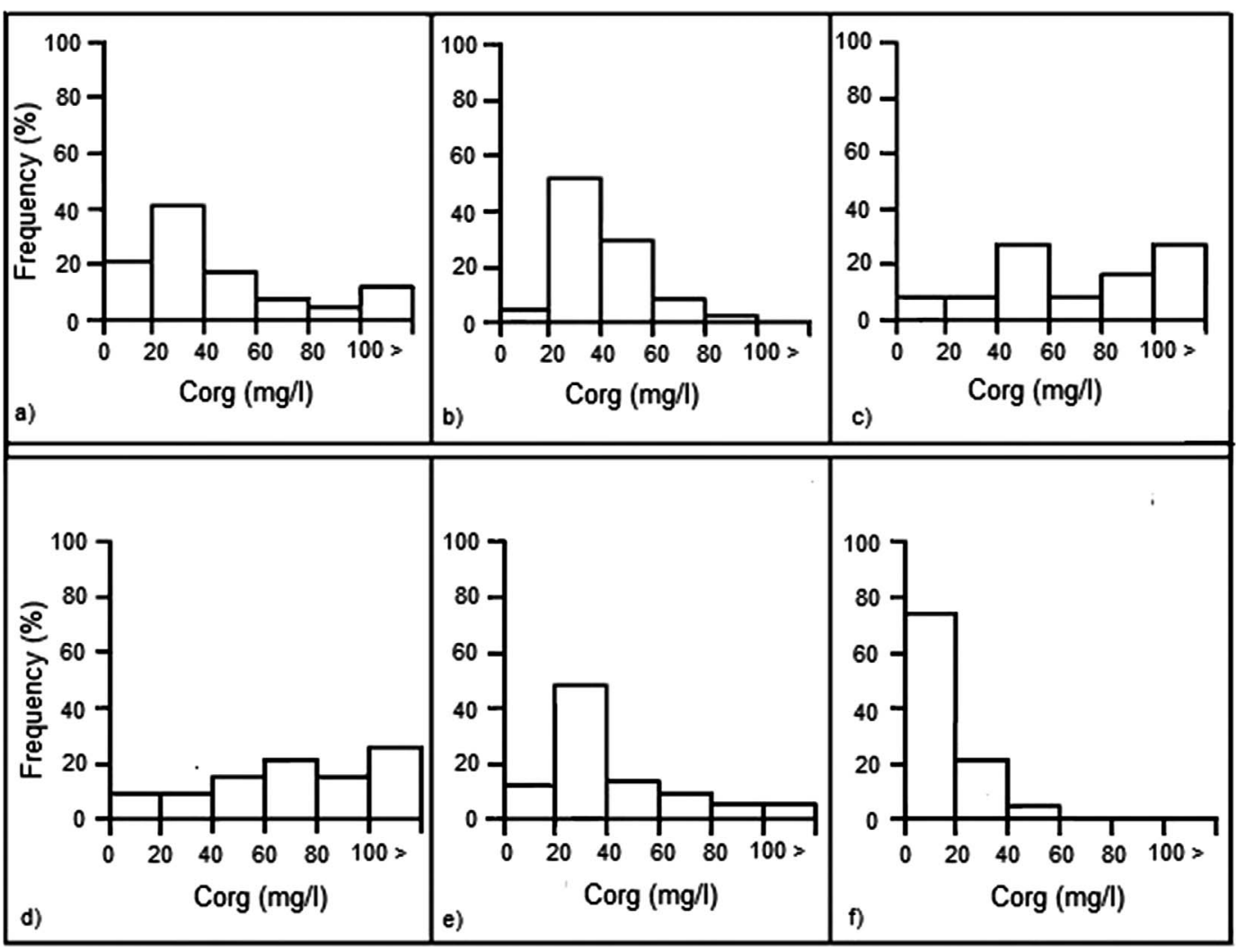

Fig. 3. $\mathrm{C}_{\mathrm{org}}$ distribution histograms in SCB formation waters for various stratigraphic intervals: (a) Pliocene; (b) upper-middle Miocene; (c) low Miocene-Oligocene (Maykop); (d) Eocene-Paleocene; (e) Cretaceous-Jurassic; (f) mud volcanoes.

Cambrian-Ordovician system in the Tarim Basin resulted from hydrocarbon-water and water-rock interactions.

Moreover, as shown by Schimmelmann and Mastalerz [29], the dynamic equilibrium is also seen in the relationship between the isotope composition of hydrogen $(\mathrm{D} / \mathrm{H})$ in oil (various fractions) and neighboring formation waters (Fig. 4).

With depth there are changes in physical conditions (temperature and pressure), chemical composition of formation waters, lithofacies (the density of rocks and their reservoir properties) and other associated processes (oil and gas formation, clay dehydration, etc.). Accordingly, of interest is to analyze DOM with hypsometric depth. Figure 5a shows that a sharp increase in the DOM values at a depth of approximately $3.3 \mathrm{~km}$. is common for various stratigraphic intervals. A similar feature is noted in the change with the depth of TOC in source rocks (Fig. 5b).

Likely, these observed increases are due to the transition of the rock-water system from a diagenesis stage (where relatively low temperatures are not sufficient for thermal decomposition of $\mathrm{OM}$ ) to the catagenetic stage, where favorable temperature conditions exist for the thermal transformation of OM into hydrocarbons. Given the relatively higher migration potential of oil and gas in comparison with their ancestral OM in the zone of catagenesis, the flow from rocks into water is accompanied by an increase of the organic component in the water and of bitumen.

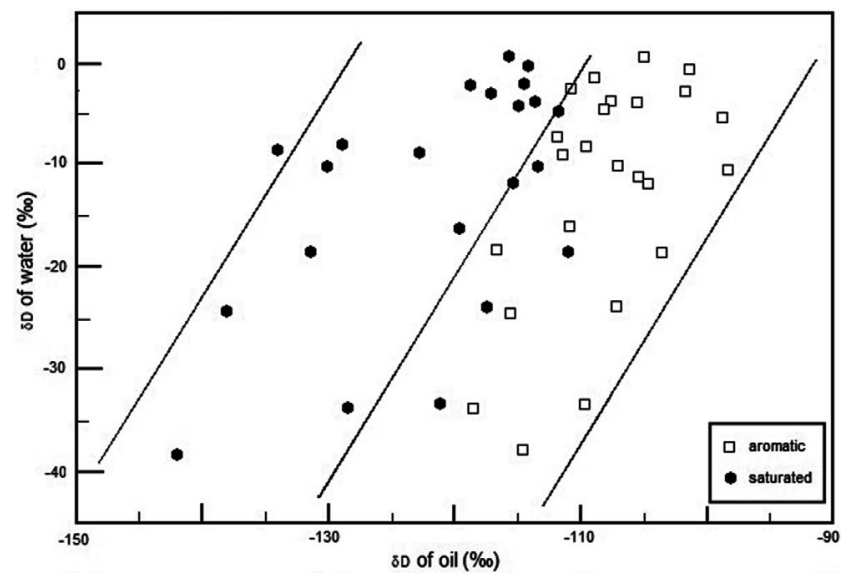

Fig. 4. Isotopic composition of hydrogen in formation waters and in various oil fractions [29].

The nature of the dependence of DOM on the carbon content of bitumen $\left(\mathrm{C}_{\mathrm{bit}}\right)$ favors this conclusion. Figure 6 shows that high contents of $\mathrm{C}_{\text {org }}$, observed at a depth greater than $3 \mathrm{~km}$ (see Fig. 5a), are characterized by high values of $\mathrm{C}_{\text {bit }}$ (Fig. 6a), a derivative of the thermal transformation of $\mathrm{C}_{\text {org }}$. A similar feature is observed in the $\mathrm{S}_{1}$ indicator (milligrams of hydrocarbon per gram of rock) during 


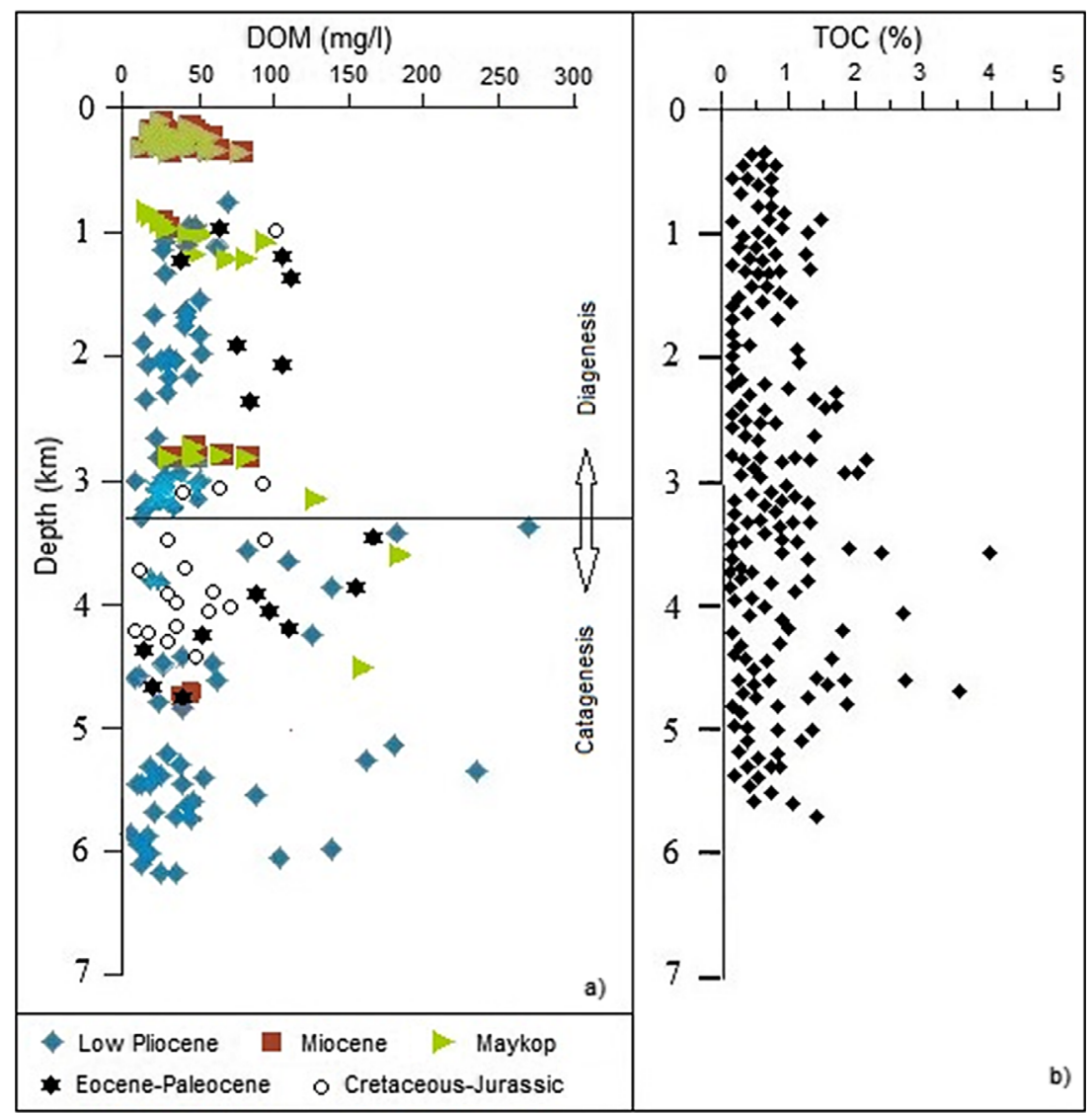

Fig. 5. Change with depth of (a) DOM and (b) TOC for various stratigraphic intervals in the SCB.
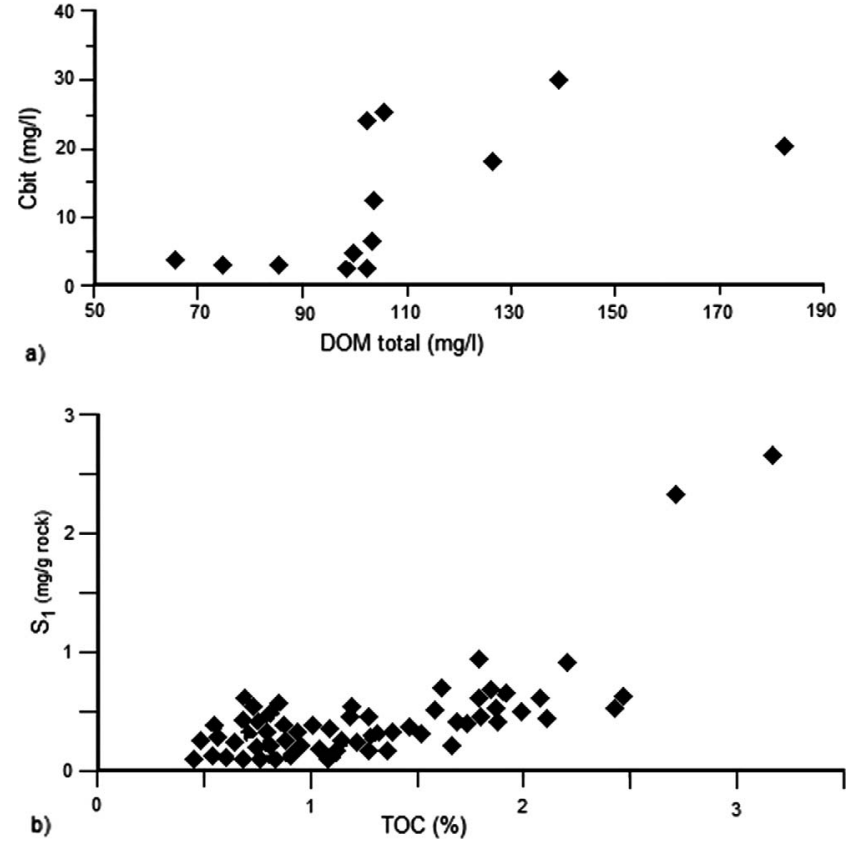

Fig. 6. Dependence of generated hydrocarbons (in water: $\mathrm{C}_{\mathrm{bit}}$; in rock; free hydrocarbons- $\mathrm{S}_{1}$ ) vs. (a) total Dissolved Organic Matter (DOM) in water and (b) Total Organic Carbon (TOC) in rock.

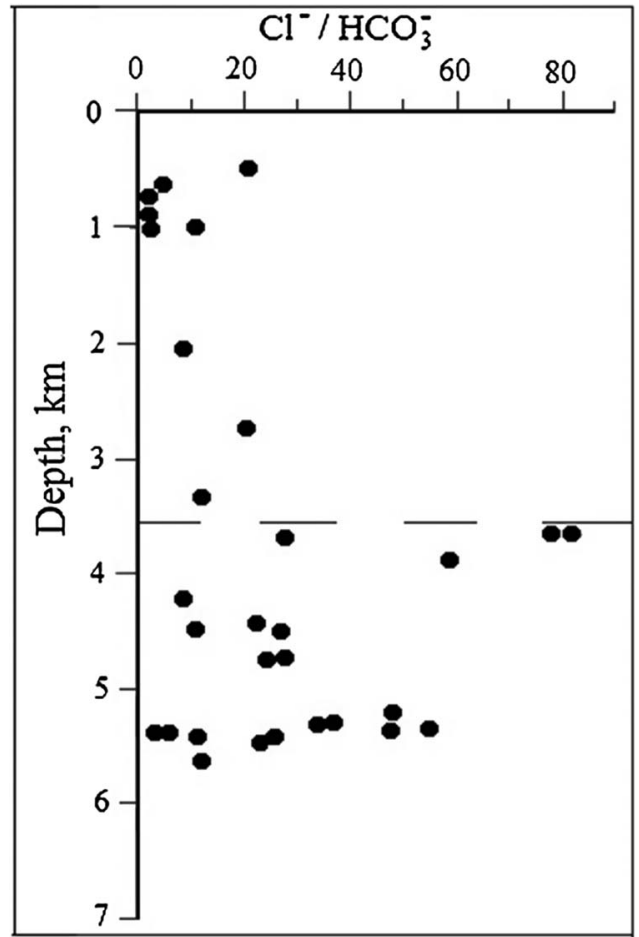

Fig. 7. Chlorine ion to bicarbonate ion ratio values vs. depth. 


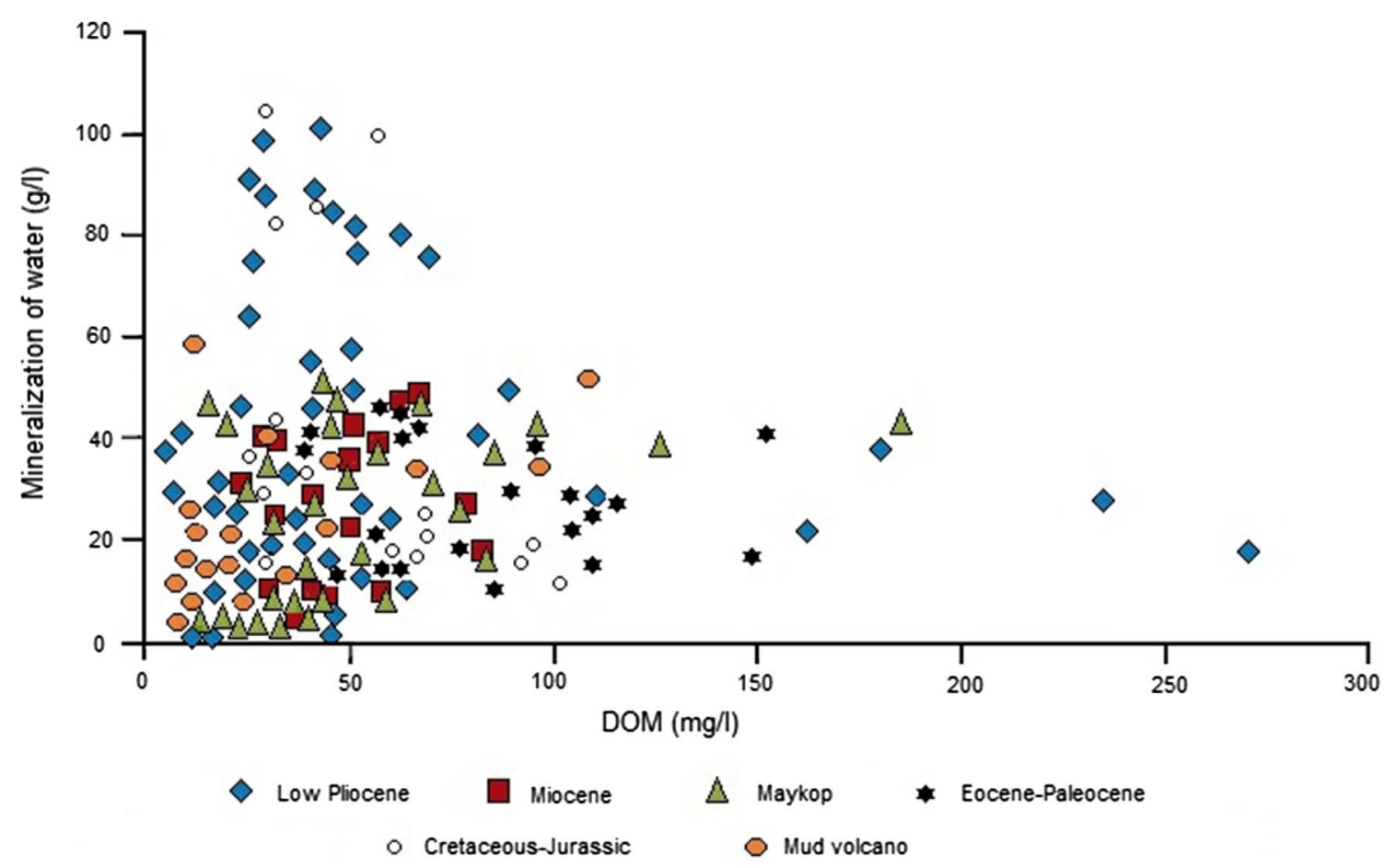

Fig. 8. DOM $(\mathrm{mg} / \mathrm{L})$ in formation waters of various stratigraphic intervals and mud volcano waters vs. mineralization of waters $(\mathrm{g} / \mathrm{L})$ in the SCB.

the pyrolysis of source rocks (Fig. 6b), indicating free hydrocarbons (gas and oil) in the sample [30].

Kartsev et al. [31] also consider that sedimentary waters dissolve hydrocarbons as a result of catagenesis and move with them to reservoir rocks. Additionally, when moving through reservoirs groundwater can dissolve more hydrocarbons and other organic compounds in the reservoir rocks. Studies conducted by Shvets [32] found that the content of DOM depends on the chemical composition of the waters. However, according to other studies [33], mineralization and chemical composition of waters can have an ambiguous effect on OM.

In this study the hydrochemical composition of the formation waters of the SCB data on the well-studied Productive Series (low Pliocene) was used. From Figure 7 one notes a pattern in the ratio of chlorine ion to the bicarbonate ion similar to the change with the depth of DOM. At approximately the same depth $(3.5 \mathrm{~km})$, a jump is observed in the $\mathrm{Cl}^{-} / \mathrm{HCO}_{3}{ }^{-}$ratio. Hence there is a relationship between the chemical composition of water and OM.

The salinity dependence of the OM content in waters is also known. For instance, investigation of DOM in the Michigan Basin (USA) established the dependence of the OM content in the formation waters on salinity [34]. There is a negative relationship between the content of DOM and the salinity of the water [35]. To study this dependence in the SCB a corresponding graph was constructed (Fig. 8).

Figure 8 shows that SCB formation waters containing high concentrations of DOM (more than $70 \mathrm{mg} / \mathrm{L}$ ) are

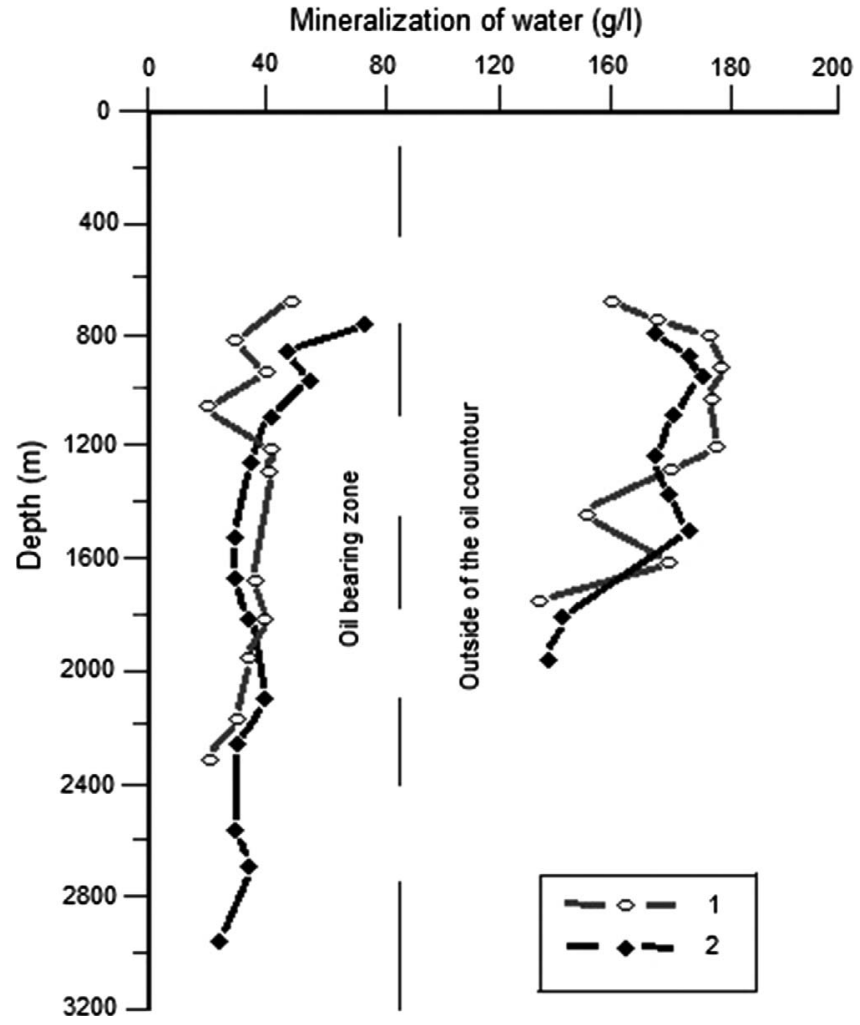

Fig. 9. Change in mineralization of formation waters with depth within and outside the oil-bearing zone on (1) Khilly and (2) Neftchala petroleum fields in the SCB [38]. 
characterized by relatively low mineralization (less than $50 \mathrm{~g} / \mathrm{L}$ ). In waters with a salinity of more than $60 \mathrm{~g} / \mathrm{L}$, the content of DOM is low and varies within the limits of $25-70 \mathrm{mg} / \mathrm{L}$. At the same time, formation waters with low DOM values (less than $20 \mathrm{mg} / \mathrm{L}$ ) and low salinity are also encountered. The same behavior was established in the Michigan Basin [34]. Such waters are also characteristic for mud volcanoes. Data from 24 analyses yields DOM in mud volcano waters varying from $7.9 \mathrm{mg} / \mathrm{L}$ to $108.5 \mathrm{mg} / \mathrm{L}$ (average $28.6 \mathrm{mg} / \mathrm{L}$ ), while water salinity ranges from $4.1 \mathrm{~g} / \mathrm{L}$ to $58.7 \mathrm{~g} / \mathrm{L}(24.2 \mathrm{~g} / \mathrm{L})$. The same behavior was also found in the study of mud volcano waters in the Taman Peninsula [36].

Low mineralization and low content of $\mathrm{OM}$ in some formation waters and mud volcano waters are likely due to their condensation genesis as confirmed by the low mineralization of formation waters that are directly connected to oil in comparison with the high mineralization waters as shown by the examples of the Neftchala and Khilly fields of the SCB (Fig. 9). Taking into account that the oil in the Productive Series is epigenetic, this pattern can be associated with phase transitions caused by changes in the thermobaric conditions during the subvertical migration of the water-oil solution. Smirnova [37] found that gas-condensate waters and those of oil-bearing deposits are characterized by very high concentrations of hydrocarbons.

\section{Conclusion}

The interaction processes between water and host rock leads to the establishment of a dynamic equilibrium in the system during geological evolution. This result explains: (1) the good convergence of the distribution of OM in rocks and formation waters of the SCB; (2) the relationship between the content of $\mathrm{OM}$ in waters and their chemical composition and mineralization; and (3) the nature of changes with depth.

The results of the studies show that underground water, as one of the components of a single rock-water system of the Earth's sedimentary cover and together with the rocks, participates in the processes of hydrocarbon generation and migration. This fundamental conclusion is important in order to obtain a complete understanding of the processes of hydrocarbon generation. Such an understanding can come only with the application of a quantitative basin analysis evaluation, well beyond the scope of the present paper.

It is also important to note factors due to prior investigations of OM in waters. Several articles [39-43] have substantiated the possibility of discovering oil and gas accumulations in the subsurface based on hydrochemical criteria. For instance, Sahay [42] notes that "Appropriate mapping of these indicators with geological and geophysical information will prove useful in the location of oil and gas".

This aspect is not considered here but additional sources of literature are provided that confirm the effectiveness of the hydrochemical criteria for hydrocarbon (HC) searches (including $\mathrm{OM}$ as a direct indicator of the presence of $\mathrm{HC}$ accumulations).
Acknowledgments. All analyses were made at the Institute of Geology and Geophysics of Azerbaijan National Academy of Sciences and we are grateful to all who took part in field and analytical investigations in particular G. Ismaylov, R. Gurbanova, Ch. Aliyev, Z. Guseynova, R. Efendiyeva, and G. Ismaylova.

\section{References}

1 Ronov A.B. (1980) Sedimentary shell of the Earth (quantitative regularity of structure, composition and evolution), Nauka Publ., Moscow, Russia. Readings dedicated to V.I. Vernadsky (in Russian)

2 Zverev V.P. (2001) Groundwater cycles in the earth's crust, Priroda 5, 3-10 (in Russian).

3 Vernadskiy V.I. (2003) History of natural waters, Nauka Publ., Moscow, Russia (in Russian).

4 Shvartsev S.L. (1997) Geological "water-rock" system, Bull. Russ. Acad. Sci. 67, 6, 518-523 (in Russian).

5 Shvartsev S.L. (2008) Fundamental mechanisms of interaction in the water-rock system and its internal geological evolution, Lithosphere 6, 3-24 (in Russian).

6 Bullen T.D., Wang Y. (2007) Water-rock interaction, in: Proceed. 12th Intern. Symp. (WRI-12), Taylor and Francis, London, UK, $1706 \mathrm{p}$.

7 Kharaka Y.K., Hull R.W., Carothers W.W. (1985) Waterrock interactions in sedimentary basins. The Society of Economic Paleontologists and Mineralogists (SEPM), Relationship of Organic Matter and Mineral Diagenesis (SC17), Chapter 2, pp. 79-272.

8 Kharaka Y.K., Land L.M., Carothers W.W. (1986) Role of organic species dissolved in formation waters from sedimentary basins in mineral diagenesis, in: Gautier D.L. (ed), Roles of organic matter in sedimentary diagenesis. SEPM Special Publications, Houston, Texas, vol. 38, pp. 111-122.

9 Harrison W.J. (1989) Modeling fluid/rock interactions in sedimentary basins. SEG Technical Program Expanded Abstracts, January 1989, pp. 595-598.

10 Fisher J.B., Boles J.R. (1990) Water-rock interaction in Tertiary sandstones, San Joaquin basin, California, U.S.A.: Diagenetic controls on water composition, Chem. Geol. 82, 83-101.

11 Altovskiy M.E., Bykova E.L., Kuznetsova Z.I., Shvets V.M. (1962) Organic matter and microflora of groundwaters and their importance in the processes of oil and gas formation, Gostoptekhizdat, Moscow, Russia (in Russian).

12 Shvets V.M. (1982) The main regularities of the distribution of organic matter in groundwater, in: Organic geochemistry of water and search geochemistry, Nauka Publ., Moscow, Russia, pp. 47-52 (in Russian)

13 Bars E.A., Selezneva L.I., Skulskaya Z.M. (1990) Watersoluble organic matter of sedimentary strata, Nauka Publ., Moscow, Russia (in Russian).

14 Zinger A.S. (1967) Organic matter of groundwater and its use for direct assessment of petroleum potential of local structures, in: Organic matter of groundwater and its importance for petroleum geology, VNIIOENG Publ., Moscow, Russia, pp. 51-61 (in Russian).

15 Zinger A.S., Dolgova R.S. (1982) Toward a theory of the organic component formation in groundwater, in: Research in the field of organic hydrogeochemistry of oil and gas bearing basins, Nauka Publ., Moscow, Russia, pp. 51-62 (in Russian). 
16 Kudryakov V.A. (1982) Organic substances of groundwater as an additional source of oil and gas, in: Sidorenko A.V. (ed), Proceedings of the VIII International Congress on Organic Geochemistry, Organic Geochemistry of Water and Search Geochemistry, pp. 62-65 (in Russian).

17 Bars E.A., Aleksandrova T.I., Viskovskiy Y.A., Polster L.A. (1967) About interrelation of organic matter of rocks and waters (on an example of Ciscaucasia), in: Bars E.A., Kogan S.S. (eds), Organic matter of groundwater and its importance for petroleum geology, VNIIOENG Publ., Moscow, Russia, pp. 62-67 (in Russian).

18 Kostikova I.A. (2002) Sedimentation waters of the Caspian sedimentary basin and fluctuations in the Caspian Sea level, PhD Thesis, Institute of Geoekology RAN, Moscow, Russia (in Russian).

19 Bailey N., Guliyev I.S., Feyzullayev A.A. (1996) Source rocks in the South Caspian, in: Proceed. AAPG/ASPG Research Symposium on Oil and gas Petroleum Systems in rapidly subsiding basins, Tulsa, Oklahoma, pp. 409-421.

20 Guliyev I.S., Feyzullayev A.A., Tagiyev M.F. (1997) Isotopegeochemical characteristics of hydrocarbons in the South Caspian Basin, Energy Explor. Exploit. 15, 4/5, 311-368.

21 Feyzullayev A.A., Guliyev I.S., Tagiyev M.F. (2001) Source potential of the Mesozoic-Cenozoic rocks in the South Caspian Basin and their role in forming the oil accumulations in the Lower Pliocene reservoirs, Pet. Geosci. 7, 4, 409-417. doi: 10.1144/petgeo.7.4.409.

22 Guliyev I.S., Feyzullayev A.A. (1996) Geochemistry of hydrocarbon seepages in Azerbaijan, in: Shumacher D., Abrams M. (eds), Hydrocarbon migration and its nearsurface expression, AAPG Memoir, pp. 63-70.

23 Katz K.J., Richards D., Long D., Lawrence W. (2000) A new look at the components of the petroleum system of the South Caspian Basin, J. Pet. Sci. Eng. 28, 161-182. doi: 10.1016/ S0920-4105(00)00076-0.

24 Gurgey K. (2003) Correlation, alteration, and origin of hydrocarbons in the GCA, Bahar, and Gum Adasy fields, western South Caspian Basin: Geochemical and multivariate statistical assessments, Mar. Pet. Geol. 20, 10, 1119-1139. doi: 10.1016/j.marpetgeo.2003.10.002.

25 Aliyev C.S, Feyzullayev A.A., Babayev S.A (2005) Radioactive and geochemical characteristics of Meso-Cenozoic deposits in the Eastern Azerbaijan and their correlation, Proc. Azerb. Nat. Acad. Sci. Ser. Earth Sci. 4, 24-27 (in Russian).

26 Kiryukhin V.K., Melkanovitskaya S.G., Shvets V.M. (1973) Evaluation of organic matter in underground waters of oil and gas bearing areas, Nedra Publ., Moscow, Russia (in Russian).

27 Shakhnovskiy I.M. (2001) Origin of oil hydrocarbons, GEOS, Moscow, Russia (in Russian).

28 Cai C., Mei B., Li W., Zeng F. (1997) Water-rock interaction in Tarim Basin: Constraints from oilfield water geochemistry, Chin. J. Geochem. 16, 4, 289-303. doi: 10.1007/ BF02870914.

29 Schimmelmann A., Mastalerz M. (2001) Isotopically labile organic hydrogen in thermal maturation of organic matter.
Summary of FY 2000 Geosciences Research. Washington, DC. 20585. Grant: DE-FG02-00ER 15032. doi: 10.1146/ annurev.earth.34.031405.125011, pp. 150-151.

30 Peters K.E. (1986) Guidelines for evaluating petroleum source rock using programmed pyrolysis, AAPG Bull. 70, 318-329. doi: 10.1306/94885688-1704-11D7-8645000102C1865D.

31 Kartsev A.A., Vagin S.B., Baskov E.A. (1969) Paleogidrogeologiya [Paleohydrogeology], Nedra Publ., Moscow, Russia (in Russian).

32 Shvets V.M. (1970) Organic substances of groundwater as oil exploration indicators (short literature review), in: Proceedings of VSEGINGEO (Moscow), Thematic Report, Organic Substances and Microflora of Groundwater and Their Exploratory Significance, 26, pp. 6-29 (in Russian).

33 Germanov A.I., Panteleev V.M. (1975) Genetical relations of organic matter and microcomponents in underground waters, Nedra Publ., Moscow, Russia (in Russian).

34 Huang R. (2008) Shale-derived dissolved organic matter as a substrate for subsurface methanogenic communities in the Antrim Shale, Michigan Basin, USA, Masters Theses, University of Massachusetts Amherst, 1911-February 2014. Retrieved from http://scholarworks.umass.edu/theses/86.

35 Chen Y., Yang G.-P., Wu G.-W., Gao X.-C., Xia Q.-Y. (2013) Concentration and characterization of dissolved organic matter in the surface microlayer and subsurface water of the Bohai Sea, China, Cont. Shelf Res. 52, 1, 97107. doi: 10.1016/j.csr.2012.11.007.

36 Aleksandrova T.I., Bars E.A. (1967) Organic matter of groundwaters in the Azov-Kuban oil and gas basin, in: Organic matter of groundwater and its importance for petroleum geology, Nauka Publ., Moscow, Russia, pp. 111-126 (in Russian).

37 Smirnova T.S. (2009) Hydrogeological and geochemical features of the hydrocarbons location within the Karpinsky shaft, PhD Thesis, Saratov University, Saratov, Russia, p. 156 (in Russian).

38 Feyzullayev A.A. (2010) Physical and chemical relationship in the sedimentary rock-fluidsystem in connection with the ontogenesis of oil and gas (the example of the South Caspian Basin), Proc. Azerb. Nat. Acad. Sci. Ser. Earth Sci. 4, 28-45 (in Russian).

39 Kortsenshtein V.N. (1964) The estimation of the possible oilgas presence according to the ground water analyses and the evaluation of the forecast of oil-gas reserves, Dokl. Akad. Nauk S.S.S.R. 158, 856-859 (in Russian).

40 Collins G. (1975) Geochemistry of oilfield waters. Development in Petroleum Sciences, Elsevier Scientific Publishing Company, Amsterdam-Oxford-New York.

41 Zorkin L.M., Subbota M.I., Stadnik E.V. (1982) Oil and gas exploration hydrogeology, Nedra Publ., Moscow, Russia (in Russian).

42 Sahay B. (2001) Petroleum exploration and exploitation practices, 3rd edn., Allied Publishers Limited, New Delhi, India.

43 Sharma A., Chaturvedi D. (2014) Geochemical methods of petroleum exploration, Int. J. Sci. Eng. Res. 5, 5, 108-112. 